\title{
TOPICAL ANALGESIC ACTIVITY OF ESSENTIAL OIL EXTRACTED FROM SPHAERANTHUS INDICUS (ASTERACEAE)
}

\author{
DIPTI KANTA PADHAN ${ }^{1 *}$, PATEL SRIBALLAV ${ }^{1}$, MOHANTY ARNABADITYA ${ }^{2}$ \\ ${ }^{1}$ Department of Pharmacognosy, the Pharmaceutical College, Bijenagar, Odisha, India. ${ }^{2}$ Department of Pharmacology, the Pharmaceutical \\ College, Bijenagar, Odisha, India. Email:diptikanta.padhan@gmail.com
}

Received: 08 February 2017, Received and Accepted: 24 February 2017

\section{ABSTRACT}

Objective: The objective of this study was to evaluate the topical analgesic effects of essential oil extracted from Sphaeranthus indicus (Asteraceae).

Methods: The essential oil was extracted from fresh flower of S. indicus. Topical ointment containing essential oil was investigated for analgesic activity in rat using hot-plate method. Diclofenac sodium gel was taken as standard drug.

Result: The analgesic activity of topical preparation was observed in the early phase. The analgesic activity of topical preparation containing $2 \%$ S. indicus flower essential oil showed significant activity $(11.5 \pm 0.34$ and $11.83 \pm 0.40)$ comparative to standard drug diclofenac sodium $(11.83 \pm 0.31$ and $12.66 \pm 0.61)$ at 90 and 120 minutes of application of drug by hot-plate method $(\mathrm{p}<0.001)$.

Conclusion: Hence, the study validates the traditional use of $S$. indicus to relive pain.

Keywords: Analgesic activity, Sphaeranthus indicus, Essential oil, Topical ointment.

(c) 2017 The Authors. Published by Innovare Academic Sciences Pvt Ltd. This is an open access article under the CC BY license (http://creativecommons. org/licenses/by/4. 0/) DOI: http://dx.doi.org/10.22159/ajpcr.2017.v10i5.17594

\section{INTRODUCTION}

Pain is defined as "an unpleasant sensory and emotional experience associated with actual or potential tissue damage [1]." Common drugs for pain relief, such as pentazocine and diclofenac, have been widely used in recent decades [2]. In most instances, these analgesic drugs, particularly opioids and nonopioids analgesic drugs can only relieve $50 \%$ of the pain in about $30 \%$ of patients [3]. In addition, many of these drugs cause serious side effects. Studies have shown that opiates cause physical dependency, tolerance, and addiction while nonsteroidal antiinflammatory drugs usually cause gastrointestinal disorders [4].

As a result, people relay on herbal medicines for alternative treatment of pain. Herbal drugs have lesser side effects, easily available and cost effective as compare to synthetic drugs [5].

Sphaeranthus indicus is a well-known folkloric drug in Ayurveda and available at plain and moist land of India [6]. Traditionally, different parts of S. indicus uses in various disorders such as bark for piles [7]; root for chest-pains, cough [8]; leaf for worm trouble, cough, dysurea, jaundice [9-12]; specially whole parts of the plant is used to relieve pain and swelling [13-16].

Hence, this study is an attempt to evaluate the topical analgesic activity of essential oil extracted from flower of the plant $S$. indicus.

In these tests, a brief noxious stimulus of short duration is applied, detected by free nerve endings and conducted through conducting neuronal pathways [17]. The hot-plate test method involves higher brain functions and is considered a supraspinally organized response [18].

\section{METHODS}

\section{Essential oil extraction}

The plant was collected from Western area of Bargarh District of Odisha, India, in the month of December 2015 and was identified by Botanical Garden, Kolkata, India, Vide Voucher Specimen No:
CNH/TECH - II/2015/24/295. Fresh flowering head of S. indicus was subjected to hydrodistillation by Clevenger apparatus for $5 \mathrm{hrs}$ [19].

\section{Preparation of herbal ointment}

Ointment base was prepared by taking polyethylene glycol $400(10 \%)$, mannitol (5\%), petroleum jelly (65\%), and liquid paraffin (20\%). Two formulation was prepared contain $1 \%$ and $2 \%$ essential oil of $S$. indicus flower [20].

\section{Animals}

Healthy adult albino rats weighing 150-200 g were used for the experiment study. Animals were maintained at $22-24^{\circ} \mathrm{C}$ with a $12 \mathrm{hrs}$ light-dark cycle. They were allowed to standard laboratory feed and water. The animals were divided into four groups and each group contains six albino rats. The study protocol was approved by the Institutional Animal Ethics Committee (Registration No. 1376/ac/10/ CPCSEA). The experimental procedures were carried out in accordance of the ethical guidelines for investigations of experimental pain in conscious animals [21].

\section{Analgesic activity}

The hot-plate method described by AbdAllah et al. was carried out to evaluate the analgesic activity of ointment containing essential oil of S. indicus flower. A hot-plate test was performed using an electronically controlled hot-plate (Eddy's hot-plate) heated to $53^{\circ} \mathrm{C}\left( \pm 0.1^{\circ} \mathrm{C}\right)$. Each rat of different groups was placed unrestrained on the hot-plate for basal reaction time measurement just before ointment base or drug application considered as zero time. The test group animals were applied with topical ointment (100 mg) at dose of $1 \%$ and $2 \% \mathrm{v} / \mathrm{w}$ on the hind paw of the albino rats. Similarly, standard and control group of animals were applied with diclofenac ointment (1.16\%) and ointment base as same as test group, respectively. 30 minutes after the drug administration, the ointment remaining on the surface of the skin was wiped off with piece of cotton. Measurements of pain threshold for the treated animals were taken after $0.5,1,1.5,2,2.5$, and $3 \mathrm{hrs}$ after drug application. Latency to lift and licking a hind paw or attempted to jump from the apparatus was recorded for the control and drug-treated 
Table 1: Analgesic activity of essential oil of $S$. indicus flower by hot-plate method

\begin{tabular}{|c|c|c|c|c|c|c|c|}
\hline \multirow[t]{2}{*}{ Treatment } & \multicolumn{7}{|c|}{ Time of treatment of the drug in minutes } \\
\hline & $\mathbf{0}$ & 30 & 60 & 90 & 120 & 150 & 180 \\
\hline Control & $4 \pm 0.26$ & $3.83 \pm 0.31$ & $3.83 \pm 0.31$ & $4.16 \pm 0.31$ & $4.16 \pm 0.31$ & $4.33 \pm 0.33$ & $4.33 \pm 0.21$ \\
\hline Test $2 \%$ & $4.17 \pm 0.31$ & $5.33 \pm 0.21$ & $8 \pm 0.37^{* *}$ & $11.5 \pm 0.34^{* *}$ & $11.83 \pm 0.40^{* *}$ & $10.67 \pm 0.49^{* *}$ & $8.67 \pm 0.42 * *$ \\
\hline Standard & $4.33 \pm 0.21$ & $5.33 \pm 0.33$ & $8.33 \pm 0.33^{* *}$ & $11.83 \pm 0.31^{* *}$ & $12.66 \pm 0.61^{* *}$ & $11.5 \pm 0.56^{* *}$ & $8.83 \pm 0.31^{* *}$ \\
\hline
\end{tabular}

$\mathrm{n}=6$; ${ }^{*} \mathrm{p}<0.05,{ }^{* *} \mathrm{p}<0.001$ values are expressed as mean \pm SEM. One-way ANOVA followed by Dunnett's t-test, all the groups are compared with control. SEM: Standard error mean, S. indicus: Sphaeranthus indicus

groups. The cutoff time was 30 seconds to avoid further tissues damage from exposure to hot-plate [22].

\section{RESULTS}

The effect of the ointment having essential oil from $S$. indicus flower on animals assayed in the hot-plate changed in doses-dependent manner as well as latency time was observed (Table 1). At time 0 and 30 minutes, no significant antinociceptive effect was observed after the treatment with the essential oil of $S$. indicus flower at both the test doses compared with control. It was observed that the results obtained after 60 minutes of the treated animals with topical ointment $1 \%$ $(10.33 \pm 0.49)$ and $2 \%(11.5 \pm 0.34)$ doses increased the basal reaction time significantly. But at 90 minutes, both the test dose of $1 \%$ and $2 \%$ showed batter result compared with control. However, standard diclofenac ointment (1.16\%) showed a potent analgesic response after at $60(8.33 \pm 0.33), 90(11.83 \pm 0.31)$, and $120(12.66 \pm 0.61)$ minutes of stimuli and increased the basal reaction time significantly as compared to control group.

\section{DISCUSSION}

As flowering head of $S$. indicus is used in traditional as analgesic [23]. This study was conducted to validate folkloric uses of the flowers of plant by traditional healer.

Essential oil component is low molecular weight compounds, usually with high lipid solubility. They can penetrate the blood-brain barrier and act in the central nervous system [24]. The hot-plate test characterizes the central analgesic activity of the oil [25]. The results depicted that topical, administration of oil at both doses $1 \%$ and $2 \%$ significantly showed best activity at 90 and 120 minutes. The hot-plate method is considered to be selective for screening of the compound acting through the opioid receptor [26]. In various studies, the action of volatile oil is attributed to the combined effect of both their active and inactive compounds. The inactive compounds might to be influence pharmacokinetics and bioavailability of the active compounds [27]. Further, it is difficult to establish a relationship between oil composition and biological activity, due to the synergistic action between the components [28]. Hence, it appears that the analgesic effect of essential oil from $S$. indicus flower is mainly due to the combined effect of terpenes and sesquiterpenes but not only by the majority constituents [29-31]. The terpenes present in the oil of plant $S$. indicus flower that may responsible for blocking the release of endogenous substances which excite the pain in nociceptive pathway [32].

\section{CONCLUSION}

Topical ointment preparation containing essential oil extracted from S. indicus flower showed potent analgesic activity at $1 \%$ and $2 \%$ doses. Further, the study is needed to find out the phytoconstituents responsible for its analgesic activity and its related mechanism.

\section{REFERENCES}

1. Pain terms: A list with definitions and notes on usage. Recommended by the IASP subcommittee on taxonomy. Pain 1979;6:249.

2. Olateju SO, Adenekan AT, Olufolabi AJ, Owojuyigbe AM, Adetoye AO, Ajenifuja KO, et al. Pentazocine versus pentazocine with rectal diclofenac for postoperative pain relief after cesarean section - A double blind randomized placebo controlled trial in a low resource area. Middle East J Anaesthesiol 2016;23:443-8.

3. Hewitt DJ, Hargreaves RJ, Curtis SP, Michelson D. Challenges in analgesic drug development. Clin Pharmacol Ther 2009;86:447-50.

4. Hanson GR, Venturelli PJ, Fleckenstein AE. Drugs and Society. $10^{\text {th }} \mathrm{ed}$. Boston, Massachusetts, USA: Jones and Bartlett; 2009.

5. Ekor M. The growing use of herbal medicines: Issues relating to adverse reactions and challenges in monitoring safety. Front Pharmacol 2014;4:177

6. Makhija IK, Richard L, Kirti SP, Saleemullah K, Jessy M, Annie S. Sphaeranthus indicus: A review of its chemical, pharmacological and ethnomedicinal properties. Int J Pharmacol 2011;7(2):171-9.

7. Nayak S, Behera SK, Misra MK. Ethno-medico-botanical survey of Kalahandi district of Orissa. Indian J Tradit Knowl 2004;3:72.

8. Kirtikar KR, Basu BD. Indian Medicinal Plant, II. Allahabad: Lalit Mohan Basu Publication; 1935. p. 1347.

9. Sen SK, Pradhan NB, Behera LM. Ethnomedicinal plants used against dysurea at Bargarh district in Orissa. Adv Plant Sci 2001;14:459-62.

10. Chopra RN, Chopra IC, Handa KL, Kapur LD. Chopras Indigenous Drug of India. Calcutta, India: U.N. Dhur and Sons; 1958. p. 601.

11. Samuel JK, Andrews B. Traditional medicinal plant wealth of Pachalur and hamlets Dindigul district, Tamil Nadu. Indian J Tradit Knowl 2010;9(2):264-70.

12. Wabale AS, Petkar AS. Ethnomedicinal plants used against jaundice by the tribals of Akole Taluka (MS). J Phytol Res 2005;18(2):259-26.

13. Jeeva S, Kiruba S, Mishra BP, Venugopal N, Dhas SS, Regini GS, et al. Weeds of Kanyakumari district and their value in rural life. Indian J Tradit Knowl 2006;5(4):501-9.

14. Nanda BK, Jena J, Rath B, Behera BR. Anagesic and antipyretic activity of whole parts of Sphaeranthus indicus Linn. J Chem Pharm Res 2009;1(1):207-12.

15. Malairajan P, Babu GV, Saral A, Mahesh S, Gitanjali. Analgesic activity of Sphaeranthus indicus Linn. Int J Drug Dev Res 2012;4:130-2.

16. Meher BR, Jena J, Rath BG. Evaluation of analgesic activity of ethanolic extract of Sphaeranthus indicus. Sch Res Libr Der Pharm Lett 2011;3(3):357-60.

17. Dennis SG, Melzack R. Comparison of phasic and tonic pain in animals. Adv Pain Res Ther 1979;3:747-60.

18. Chapman CR, Casey KL, Dubner R, Foley KM, Gracely RH, Reading AE. Pain measurement: An overview. Pain 1985;22(1):1-31.

19. Viljoen AM, Subramoney S, van Vuuren SF, Baser KH, Demirci B. The composition, geographical variation and antimicrobial activity of Lippia javanica (Verbenaceae) leaf essential oils. J Ethnopharmacol 2005;96(1-2):271-7.

20. Chhetri HP, Yogol NS, Sherchan J, Anupa KC, Mansoor S, Thapa P. Formulation and evaluation of antimicrobial herbal ointment. Kathmandu Univ J Sci Eng Technol 2010;6(1):102-7.

21. Zimmermann M. Ethical guidelines for investigations of experimental pain in conscious animals. Pain 1983;16(2):109-10.

22. Abdallah FI, Dawaba HM, Mansour A, Samy AM. Evaluation of the antiinflammatory and analgesic effects of piroxicam loaded microemulsion in topical formulations. Int J Pharm Pharm Sci 2011;3(2):66-70.

23. Galani VJ, Patel BG, Rana DG. Sphaeranthus indicus Linn: A phytopharmacological review. Int J Ayurveda Res 2010;1(4):247-53.

24. de Sousa DP. Analgesic-like activity of essential oils constituents. Molecules 2011;16(3):2233-52.

25. Ghori SS, Ahmed MI, Arifuddin M, Khateeb MS. Evaluation of analgesic and anti inflammatory activities of formulation containing camphor, menthol and thymol. Int J Pharm Pharm Sci 2016;8(1):271-4.

26. Sarmento-Neto JF, Nascimento LG, Felipe CF, Sousa de DP. Analgesic potential of essential oils. Molecules 2016;21(20):1-29.

27. Svoboda KP, Deans SG. Biological activities of essential oils from 
selected aromatic plants. Acta Hortic 1995;390(1):203-9.

28. Tadrent W, Bachari K, Kabouche Z. Comparative compositions and antibacterial activity of the essential oils of Anthemis nobilis L. and Anthemis mixta L. (Asteraceae). Int J Pharm Pharm Sci 2016;8(7):457-9.

29. Cabo J, Crespo ME, Jimenez J, Zarzuelo A. The spasmolytic activity of various aromatic plants from the province of Granada. I. The activity of the major components of their essential oils. Plant Med Phytother 1986;20:213-8.

30. Santos FA, Rao VS. Antiinflammatory and antinociceptive effects of 1,8-cineole a terpenoid oxide present in many plant essential oils. Phytother Res 2000;14(4):240-4.

31. Ozbek H, Tas A, Ozgokce F, Selcuk N, Alp S, Karagoz S. Evaluation of median lethal dose and analgesic activity of Foeniculum vulgare miller essential oil. Int J Pharmacol 2006;2:181-3.

32. Lee SK, Hong CH, Huh SK, Kim SS, Oh OJ, Min HY, et al. Suppressive effect of natural sesquiterpenoids on inducible cyclooxygenase (COX2) and nitric oxide synthase (iNOS) activity in mouse macrophage cells. J Environ Pathol Toxicol Oncol 2002;21(2):141-8. 